\section{Manajemen Pelayanan Publik: Tinjauan tentang Keadilan Akses Pelayanan Publik Bagi Kaum Difabel}

\section{Jovano Deivid Oleyver Palenewen}

Program Studi Ilmu Pemerintahan, Universitas Palangka Raya.

Korespodensi Penulis. E-mail: jovano.palenewen@yahoo.com

Abstrak
Kemerdekaan yang di alami oleh
Indonesia, merupakan poin masuk
dalam keseriuasan $r$ untuk
mewujudkan pembangunan dalam
segala bidang. Pembangunan ini
dilandasi dalam Pancasila sebagai
dasar Negara, sehingga yang
diharapkan pembangunan suatu
Negara, melekat nilai-nilai Pancasila
termasuk diantaranya nilai keadilan
sosial. Salah satu ukuran yang dipakai
dalam pembangunan suatu Negara
yaitu kualitas dari pelayanan publik
atau manjaemen pelayanan publik.
Pelayanan publik yang dimaksudkan
ialah Negara hadir, untuk
memberikan pelayanan kepada warga
Negara (masyarakat) secara adil dan
merata. Akan tetapi jika ilihat pada
masa sekarang Negara belum mampu
memberi pelayanan secara merata
kepada segenap warga Negara. Hal ini
Nampak bagi pelayanan kepada kaum
difabel, dimana keberadaan mereka
sebagai warga Negara sering
mendapat kesulitan dalam mengakses
pelayanan yang disiapkan oleh
Negara. Dengan asumsi yang
dibangun bahwa Negara harus
menjamin dan mengkomodir

kepentingan dan keberadaan mereka (kaum difabel) yang sesuai dengan pancasila. Tulisan ini mencoba memberi penjelasan mengenai penerapan nilai pancasila menyangkut nilai keadilan yang dilakukan oleh Negara kepada warga Negara khususnya bagi kaum difabel, dalam mengakses pelayanan publik.

Kata kunci: Keadilan, Pelayanan Publik, Difabel.

Public Service Management:

\section{Overview of Justice Access to Public Services for People with Disabilities}

\begin{abstract}
The independence that was experienced by Indonesia was an entry point in the seriousness of realizing development in all fields. This development is based on Pancasila as the basis of the State, so that what is expected for the development of a State is attached to the values of Pancasila including the value of social justice. One measure used in the development of a country is the quality of public services or the management of public services. The intended public service is the State is present, to provide services to citizens (communities) in a fair and equitable manner. However, if seen at the present time the State has not been able to provide services evenly to all citizens. This appears to be for services to persons with disabilities, where their existence as citizens often has difficulty accessing services prepared by the State. With the assumption that the State must guarantee and accommodate the interests and existence of them (persons with disabilities) in accordance with Pancasila. This paper tries to provide an explanation of the application of the value of Pancasila regarding the value of justice carried out by the State to
\end{abstract}


citizens, especially for people with disabilities, in accessing public services.

Keywords: Justice, Public Services, Disability.

\section{A. PENDAHULUAN}

Pancasila merupakan dasar negara Indonesia yang mengandung nilai-nilai sebagai pedoman hidup berbangsa dan bernegara. Selain itu, Pancasila menjadi pandangan hidup dan jiwa dari negara Indonesia dan mengikat bagi setiap orang. Sebagai ideologi bangsa, Pancasila memuat nilai-nilai dalam kelima silanya. Sementara sebagai suatu dasar ideologi dan dasar falsafah negara, Pancasila juga memberikan pengakuan terhadap harkat serta martabat manusia yang secara intrinsik melekat pada sila-silanya (Hadjon, 1987). Pengakuan tersebut tidak secara langsung tertulis pada silanya tetapi dapat dilihat dari makna dan nilai yang terkandung dalam kelima sila Pancasila.

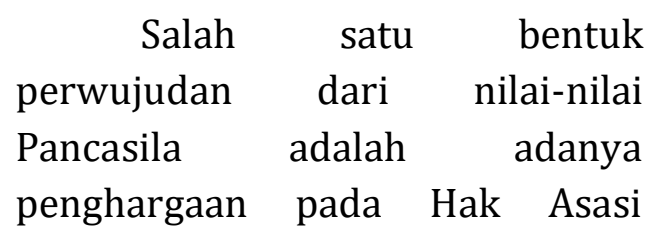
Manusia (HAM.) Penghormatan dan pelaksanaan atas nilai-nilai dari HAM dilakukan dalam acuan ideologis negara dan bangsa. Keberadaan HAM di Indonesia bukanlah dimaksudkan untuk memasuki individualisme tetapi lebih ke arah menunjukkan sisi praktis dari ideologi Pancasila yang di antaranya adalah menjunjung tinggi kemanusiaan dan mengartikulasikan kesetaraan antar unsur dalam kebhinekaan Indonesia (Sutrisno, 2006). HAM sendiri dalam hal ini bukanlah suatu tujuan, melainkan suatu sarana dan wahana penghormatan serta pemuliaan bagi nilai-nilai kemanusiaan dan kebangsaan menuju tercapainya tujuan negara. Hal demikian sejatinya menunjukkan bahwa Pancasila sebagai dasar negara Indonesia telah secara tersirat memberikan perlindungan terhadap HAM.

Sebagaimana diketahui bahwa HAM pada dasarnya terkait dengan pandangan bahwa manusia memiliki kesamanaan derajat, sehingga berhak untuk mendapat berbagai perlakuan yang sama. Wujud nyata dari hal tersebut dapat dilihat dalam sila kedua Pancasila, yaitu "Kemanusiaan yang Adil dan Beradab". Terkait dengan sila tersebut, dalam hal ini negara berkewajiban untuk menjamin hak dan kebebasan dasar pada setiap individu (Harkrisnowo, 2003).

Kemanusiaan yang adil dan beradab sebagai sila kedua Pancasila mengandung nilai kemanusiaan, yaitu pengakuan terhadap adanya martabat manusia dengan segala hak asasinya yang harus dihormati oleh siapapun, dan perlakuan yang adil terhadap sesama manusia (Suhadi, 2003). Berdasarkan aspek kemanusiaan dalam Pancasila, maka dapat dikatakan bahwa 
setiap unsur dalam penyelenggaraan negara harus memuat perlindungan atas nilainilai kemanusiaan sebab nilai tersebut merupakan bagian dari hal yang dijunjung pada Pancasila. Beberapa makna yang terkandung dalam sila kedua Pancasila di antaranya a) hak atas hidup yang berkualitas, hak atas rasa aman dari ancaman, serangan atau derita apapun dimiliki oleh setiap individu; b) setiap individu memiliki kebebasan mendasar yang dijamin negara dan hanya dibatasi oleh kebebasan orang lain; c) setiap individu harus diberlakukan sama oleh negara tanpa melihat asal-usul biologis maupun sosialnya; d) setiap individu harus dilindungi dan berhak untuk tidak disiksa secara psikis maupun psikologis oleh pejabat publik (Harkrisnowo, 2003).

Berdasarkan keempat makna yang terkandung dalam sila kedua Pancasila tersebut, dapat dilihat bahwa pada dasarnya prinsip yang terkandung dalam sila kedua Pancasila merupakan landasan berperilaku terhadap sesama manusia di Indonesia. Pada keempat makna tersebut terdapat hak untuk diberlakukan sama oleh negara yang merupakan salah satu bentuk hak kemanusiaan paling mendasar.

Ketetuan tersebut tentunya berlaku pula untuk penyelenggaraan pelayanan publik di negara Indonesia. Pelayanan publik mengenal adanya aktor yang menyediakan jasa layanan atau pemberi layanan selanjutnya terdapat aktor penerima layanan atau menikmati layanan yang diberikan penyedia layanan. Hal ini pelayanan publik sebagai pemberian pelayanan prima kepada masyarakat yang merupakan perwujudan kewajiban aparatur pemerintah sebagai abdi masyarakat (Ratminto dan Winarsih, 2009). Terkait dengan perwujudan nilai-nilai Pancasila dalam semua aktivitas berbangsa dan bernegara, maka tentu khususnya penyelenggaraan pelayanan publik yang ada di Indonesia dalam hal ini harus diberikan secara adil bagi seluruh masyarakat. Artinya bahwa setiap masyarakat yang memiliki kebutuhan atas pelayanan publik tersebut harus dapat dijamin aksesnya pada pelayanan publik tersebut. Termasuk dalam hal ini adalah kelompok difabel (people with different ability) yang memiliki kemampuan khusus. Pengalaman dilapangan pelayanan publik yang diberikan oleh pemerintah maupun sektor swasta kurangnya keberpihakan terhadap kelompok difabel. Hal ini Nampak, seperti dalam hal ketersediaan fasilitas layanan bagi kaum difabel dalam mengakses pelayanan publik baik dalam pembuatan identitas kependudukan (KTP, KK dan Identitas Lainnya) serta di tempat pelayanan kesehatan baik puskesmas dan rumah sakit. Ini 
Vol.1 No.1 Juni 2019

harus disadari secara kewarganegaraan mereka sebagai warga negara yang harus mendapat jasa yang baik dalam pelayanan dengan pertimbangan kondisi mereka.

\section{B. TEORI (Literature Review)}

Pelayanan publik pada dasarnya untuk memenuhi kebutuhan masyarakat oleh penyelenggara negara, dalam hal ini adalah pemerintah. Kebutuhan masyarakat yang dimaksud bukanlah kebutuhan yang sifatnya individual tetapi kebutuhan yang diharapkan masyarakat umum (Sinambela, dkk., 2006). Hal demikian menunjukkan bahwa pelayanan publik harus dimaknai sebagai bentuk pemenuhan kebutuhan masyarakat umum. Oleh sebab itu, akses terhadap pelayanan publik selayaknya dibuka untuk seluruh kalangan masyarakat, sehingga semua masyarakat dapat menikmati dengan baik setiap pelayanan yang diberikan oleh pemerintah dalam setiap level pemerintahan baik pemerintah pusat, pemerintah daerah sampai pemerintah desa.

Pemahaman

tentang

Pelayanan publik sering dipahami juga sebagai pemberian layanan atau melayani keperluan masyarakat yang mempunyai kepentingan pada organisasi itu sesuai dengan aturan pokok dan tata cara yang telah ditetapkan (Sinambela, dkk., 2006). Oleh sebab itu, penyelenggaraan pelayanan publik ditujukan secara luas bagi masyarakat umum, yang merupakan warga negara. Pandangan dalam perspektif kewarganegaraan bahwa warga negara selain dicatat sebagai keanggotaan dalam suatu negara (membership) dalam status warga negara terdapat juga adanya hak dan kewajiban yang harus di terima dan dilakukan oleh masyarakat sebagai warga negara, termasuk masyarakat mendapat hak untuk menikmati pelayanan publik dengan baik.

Praktek penyelenggaraan pelayanan publik di negara Indonesia harus dilaksanakan berdasarkan prinsip nilai-nilai pancasila serta konstitusi yang dijabarkan dalam peraturan perundang-undangan didalamnya asas-asas umum pemerintahan yang baik, yaitu kepastian hukum, transparan, daya tanggap, berkeadilan, efektif dan efisien, tanggung jawab, akuntabilitas, tidak menyalah gunakan wewenang (Surjadi, 2009). Banyak hal yang bisa kita gambarkan tentang beberapa contoh pelayanan, baik bidang kesehatan, ekonomi, pendidikan dan politik. Pada intinya, setiap pelayanan yang dilaksanakan haruslah berbasis pada kepentingan masyarakat serta mampu memberikan rasa puas dan keadilan bagi para pengguna layanan. Hal tersebut menunjukkan bahwa prinsip keadilan merupakan salah satu 
Vol.1 No.1 Juni 2019

$\begin{array}{llr}\text { prinsip utama dalam } & \text { dalan } \\ \text { penyelenggaraan } & \text { pelayanan }\end{array}$ publik. Oleh sebab itu, menjadi sangat berasalan bahwa pemerintah sebagai penyelenggara pelayanan publik kemudian dituntut untuk mampu membuka akses pelayanan bagi seluruh masyarakat secara adil.

\section{METODE}

Dalam artikel ini metodenya menggunakan jenis penelitian kualitatif, karena mencoba untuk mengeksplor suatu tinjauan mengenai prinsip keadilan dalam nilai pancasila dalam penerapannya di suatu konteks pelayanan publik bagi kaum difabel. Data yang diperoleh malalui studi kepustakaan dengan menggunakan berbagai literasi.

\section{HASIL DAN PEMBAHASAN}

Salah satu bentuk alat ukur demokrasi yang sedang diampu oleh sebuah pemerintahan adalah dengan menimbang kemampuan negara tersebut dalam memenuhi dan menjamin hak-hak warga negaranya (Thohari, 2014). Dalam hal ini, negara merupakan pelindung bagi hak-hak semua warga negara yang dimilikinya. Terkait dengan hal tersebut, maka negara kemudian dituntut untuk menyediakan pelayanan publik yang sesuai dengan kebutuhan masyarakat.

Penyelenggaraan pelayanan publik oleh pemerintah dalam hal ini tidak dapat dilepaskan dari unsur aksesibilitas. UndangUndang No 4 Tahun 1997 tentang Penyandang Cacat Pasal 1 ayat (4) menyatakan bahwa "Aksesibilitas adalah kemudahan yang disediakan bagi penyandang cacat guna mewujudkan kesamaan kesempatan dalam segala aspek kehidupan dan penghidupan". Ketentuan ini diperjelas dalam Pasal 10 ayat (2) ndang-Undang No 4 Tahun 1997 tentang Penyandang Cacat yang menyatakan bahwa "Penyediaan aksesibilitas dimaksudkan untuk menciptakan keadaan lingkungan yang lebih menunjang penyandang cacat dapat sepenuhnya hidup bermasyarakat".

Berdasarkan uraian tersebut, dapat dikatakan bahwa negara melalui ketentuan peraturan perundang-undangan berupaya untuk mewujudkan kesamaan kesempatan dalam segala aspek kehidupan dan penghidupan agar difabel dapat sepenuhnya hidup bermasyarakat. Tujuan tersebut diwujudkan dengan memberikan kemudahankemudahan aksesibilitas bagi para difabel (Thohari, 2014). Termasuk dalam hal ini adalah aksesibilitas pada pelayanan publik.

Aksesibilitas masyarakat terhadap pelayanan publik menjadi sangat penting, karena pelayanan publik yang diselenggarakan pemerintah tidak dapat memberi kemanfaatan optimal bagi masyarakat apabila tidak dapat diakses oleh 
masyarakat. Oleh sebab pemerintah kemudian tidak hanya dituntut untuk mampu menyelenggarakan pelayanan publik yang sesuai dengan kebutuhan masyarakat, tetapi juga harus mampu memastikan bahwa pelayanan publik yang diselenggarakan pemerintah dapat diakses oleh masyarakat (Thohari, 2014). Terutama bagi penyandang disabilitas, karena tanpa aksesibilitas tersebut maka kelompok disabilitas akan tersisih dari manfaat pelayanan publik.

Undang-Undang Nomor 4 Tahun 1997 tentang Penyandang Cacat pada Pasal 1 angka 1 menyatakan bahwa "Penyandang cacat adalah setiap orang yang mempunyai kelainan fisik dan/atau mental, yang dapat mengganggu atau merupakan rintangan dan hambatan baginya untuk melakukan secara selayaknya." Pada makalah ini, istilah yang digunakan untuk menyebut penyandang cacat adalah difabel.

Kelompok

difabel

merupakan bagian dari masyarakat yang juga dilindungi hak-haknya. Indonesia dalam hal ini telah meratifikasi Convention on The Rights of Persons with Disabilities melalui UndangUndang Nomor 19 Tahun 2011 tentang Pengesahan Convention on The Rights of Persons with Disabilities (Konvensi Mengenai Hak-Hak Penyandang Disabilitas). Ratifikasi tersebut menunjukkan dua hal. Pertama adalah bahwa perlindungan hak kaum difabel telah menjadi perhatian internasional. Kedua, pemerintah Indonesia sejalan dengan pemerintah negara lain untuk memberi perlindungan hak-hak kaum difabel. Ketentuan pejelasan umum dari Undang-Undang tersebut pada paragraf 1 menyatakan bahwa:

“Negara Republik Indonesia yang berdasarkan Pancasila dan Undang-Undang Dasar Negara Republik Indonesia Tahun 1945 menghormati dan menjunjung tinggi harkat dan martabat manusia. Hak asasi manusia sebagai hak dasar yang secara kodrati melekat pada diri manusia, bersifat universal dan langgeng, juga dilindungi, dihormati, dan dipertahankan oleh Negara Republik Indonesia, sehingga perlindungan dan pemajuan hak asasi manusia terhadap kelompok rentan khususnya penyandang disabilitas perlu ditingkatkan."

Uraian tersebut menunjukkan bahwa dalam hal ini Indonesia secara peraturan perundang-undangan telah memiliki komitmen untuk memberikan perlindungan pada kelompok difabel. Perlindungan tersebut diperlukan mengingat kelompok difabel termasuk dalam kelompok yang rentan. Selain itu, perlindungan tersebut juga menjadi perwujudan Indonesia 
sebagai negara yang melindungan hak-hak asasi manusia. Terkait dengan hal tersebut, ndangUndang Nomor 19 Tahun 2011 menyebutkan berbagai peraturan perundangan yang menjadi bentuk perlindungan terhadap hak-hak difabel. Salah satunya adalah Undang-Undang Nomor 25 Tahun 2009 tentang Pelayanan Publik.

Undang-Undang Nomor 25

Tahun 2009 tentang Pelayanan Publik pada Pasal 4 menyebutkan beberapa asas dalam penyelenggaraan pelayanan publik. Salah satu aasnya yaitu bahwa penyelenggaraan pelayanan publik berasaskan persamaan perlakuan atau tidak diskriminatif, serta fasilitas dan perlakuan khusus bagi kelompok rentan. Ketentuan tersebut menunjukkan bahwa kelompok difabel tidak hanya harus dijamin aksesnya atas pelayanan publik secara sama dengan masyarakat umum lainnya, tetapi juga dijamin atas aksesnya pada fasilitas dan perlakuan khusus dalam penyelenggaraan pelayanan publik.

Sementara itu, lebih lanjut dalam Pasal 29 Undang-Undang Nomor 25 Tahun 2009 tentang Pelayanan Publik diatur hal berikut a) penyelenggara berkewajiban memberikan pelayanan dengan perlakuan khusus kepada anggota masyarakat tertentu sesuai dengan peraturan perundang-undangan; b) sarana, prasarana, dan/ atau fasilitas pelayanan publik dengan perlakuan khusus sebagaimana dimaksud pada ayat (1) dilarang digunakan oleh orang yang tidak berhak.

Pada ketentuan penjelasaannya, perlakuan khusus kepada anggota masyarakat tertentu sebagaimana diatur dalam Pasal 29 ayat (1) Undang-Undang Nomor 25 Tahun 2009 tentang Pelayanan Publik merujuk pada beberapa kelompok masyarakat. Di antaranya adalah penyandang cacat, lanjut usia, wanita hamil, anak-anak, korban bencana alam, dan korban bencana sosial. Berdasarkan uraian tersebut, dapat dilihat dengan jelas bahwa dalam hal ini peraturan perundang-undangan telah mengamanatkan penyelenggaraan pelayanan publik yang ramah bagi kaum difabel.

Pada kenyataannya, tidak dapat dipungkiri bahwa penyelenggaraan pelayanan publik saat ini belum cukup mampu menjamin hak-hak difabel atas aksesnya terhadap pelayanan publik. Khususnya di negara berkembang seperti Indonesia, terabaikannya masalah difabel ini disebabkan oleh adanya faktor sosial budaya, selain faktor ekonomi dan lemahnya kebijakan atau penegakan hukum yang memihak komunitas difabel. Hal ini tidak jarang menyebabkan difabel terabaikan dalam segala aspek kehidupan (Harahap dan Bustanudin, 2015). Termasuk pula adalah tidak terjaminnya hak-hak 
difabel untuk mengakses pelayanan publik, baik pelayanan pendidikan, kesehatan, transportasi, dan berbagai bentuk pelayanan publik lainnya.

Keterbatasan akses kaum difabel pada pelayanan publik salah satunya terjadi karena belum adanya perhatian khusus pemerintah sebagai penyelenggara pelayanan publik atas fasilitasfasilitas pelayanan yang mendukung terbukanya akses bagi difabel. Sebagaimana diketahui, dalam proses perencanaan dan desain bangunan atau lingkungan pelayanan publik di berbagai wilayah, komunitas difabel belum mendapat perhatian para kelompok profesional, khususnya para pendidik dan perancang bangunan. Selain itu para pengambil kebijakan tidak secara tegas memberlakukan adanya peraturan hukum tentang aksesibilitas kepada seluruh jajaran pemerintah yang menyelenggarakan pelayanan publik (Harahap dan Bustanudin, 2015). Kondisi inilah yang semakin memperburuk akses kelompok difabel terhadap pelayanan publik.

Tidak dapat dipungkiri bahwa fakta di lapangan menunjukkan masih minimnya sarana pelayanan sosial dan kesehatan serta pelayanan lainnya yang dibutuhkan oleh para difabel, termasuk aksesibilitas terhadap pelayanan publik yang dapat mempermudah kehidupan difabel. Dalam hal ini, sebagian besar hambatan aksesibilitas difabel terhadap pelayanan publik tersebut adalah berupa hambatan arsitektural (Firdaus dan Iswahyudi, 2008). Kondisi tersebut membuat difabel cenderung kehilangan haknya dalam mendapatkan pelayanan publik yang baik sebagaimana menjadi haknya sebagai bagian dari masyarakat.

Penyelenggara pelayanan publik di Indonesia dalam hal ini dapat mengambil pelajaran dari mekanisme perlindungan difabel atas haknya mengakses pelayanan publik di negara maju. Misalnya adalah di Amerika Serikat. Negara tersebut dapat dikatakan satu langkah lebih maju dalam memberikan apresiasi dan pengakuan hak-hak difabel. Hal ini terlihat dengan adanya peraturan hukum yang berfungsi efektif untuk memproteksi hak-hak dasar difabel seperti aksesibilitas lingkungan dan bangunan, penyediaan lapangan pekerjaan dan pendidikan yang layak, serta jaminan sosial bagi difabel yang mengalami disabilitas cukup serius. Keseluruhannya diatur dalam American Disability of Act (ADA) yang mengatur sekaligus memproteksi hak-hak difabel dalam akses pendidikan, perumahan, lapangan pekerjaan, kesehatan, sampai dengan sosial security (Harahap dan Bustanudin, 2015). Urian tersebut menunjukkan bahwa terdapat keseriusan pemerintah untuk 
benar-benar melindungi hak warganya yang merupakan difabel dalam mengakses berbagai bentuk pelayanan publik.

Tidak hanya berhenti sebagai suatu peraturan perundang-undangan saja, ketentuan tersebut terbukti mampu mencapai hasil positif. Hal ini terlihat dari banyaknya bangunan publik di Amerika dan sikap masyarakatnya yang mampu menerima dalam berinteraksi dengan difabel. Hampir semua bangunan publik mudah diakses dan ramah baik bagi difabel. Mulai dari fasilitas umum seperti subway, bus, bangunan sekolah, dan gedung-gedung fasilitas publik lainnya yang menunjukkan ketersediaan aksesibilitas bagi difabel (Harahap dan Bustanudin, 2015). Kondisi tersebut membuat difabel menjadi lebih mandiri dan lebih mudah mengekspresikan kemampuannya untuk berinteraksi sosial secara wajar dan optimal. Artinya bahwa dalam hal ini kemudahan akses difabel pada pelayanan publik juga menjadi bentuk pemberdayaan tersendiri bagi kelompok difabel untuk menjadi lebih mandiri dan memiliki hubungan sosial selayaknya anggota masyarakat lainnya.

Difabel dalam hal ini juga merupakan warga negara Republik Indonesia yang dalam UndangUndang Dasar 1945 dijamin untuk memiliki kedudukan, hak, kewajiban, dan peran yang sama dengan warga negara lainnya (Firdaus dan Iswahyudi, 2008). Guna mencapai pembangunan nasional yang bertujuan mewujudkan masyarakat adil dan makmur berdasarkan Pancasila dan Undang-Undang Dasar 1945, maka pemerintah hendaknya juga mampu menjamin atau memberikan perhatian kepada para difabel, termasuk terkait dengan akses pada pelayanan publik.

Apabila dilihat dari peraturan perundangundangannya, Indonesia saat ini telah memiliki cukup banyak peraturan yang mengatur berbagai hal terkait aksesibilitas pelayanan dan fasilitas publik untuk masyarakat dengan kebutuhan khusus. Peningkatan kualitas hidup bagi kelompok masyarakat difabel dalam hal ini didasarkan atas prinsip kesetaraan (persamaan) kesempatan dan partisipasi dalam berbagai aspek hidup. Terutama yang terkait dengan masalah aksesibilitas, rehabilitasi, kesempatan kerja, kesehatan, serta pendidikan. Landasan kebijakan untuk peningkatan kualitas hidup difabel yang didasarkan atas prinsip kesetaraan (persamaan) kesempatan dan partisipasi dalam berbagai aspek hidup dan kehidupan khususnya terkait dengan aksesibilitas, rehabilitasi, kesempatan kerja, kesehatan serta pendidikan, secara umum sudah cukup tersedia baik pada tataran 
konstitusional maupun peraturan perundang undangan (Firdaus dan Iswahyudi, 2008). Oleh sebab itu, permasalahan mendasar yang perlu dilihat dalam hal ini adalah aspek implementasinya sehingga penyelenggaraan pelayanan publik yang telah diatur tersebut dapat benar-benar diakses secara adil oleh difabel.

\section{E. SIMPULAN DAN SARAN}

Berdasarkan uraian yang telah dipaparkan, dapat dikatakan bahwa Pancasila menjamin adanya keadilan bagi setiap warga negara Indonesia untuk mengakses pelayanan publik dengan baik. Secara normatif dalam hal ketentuan peraturan perundangundangan telah berupaya untuk menjamin aksesibilitas kaum difabel terhadap pelayanan publik yang sejalan dengan nilai-nilai yang terkandung dalam Pancasila. Terutama adalah sila kedua, di mana difabel juga merupakan individu bagian dari warga negara Indonesia yang harus diperlakukan sama serta memiliki hak untuk mengakses pelayanan publik yang sama dengan individu lain.

\begin{tabular}{lrr}
\multicolumn{1}{c}{ Meski } & \multicolumn{1}{c}{ masih } & terdapat \\
beberapa & kendala & dari \\
implementasi & menyangkut \\
ketentuan-ketentuan & tentang \\
peraturan tersebut yang belum & beluan \\
dijalankan secara optimal, Akan \\
tetapi hal ini perlu ada komitmen \\
bersama oleh semua pihak, baik \\
pemerintah swasta dan \\
masyarakat dalam menciptakan
\end{tabular}

satu kondisi pelayanan publik yang ramah bagi kaum difabel, sehingga nilai keadilan bagi warga negara Indonesia dapat terealisasi dengan baik.

\section{DAFTAR PUSTAKA}

Firdaus, F., dan Iswahyudi, F. 2008. Aksesibilitas dalam

Pelayanan Publik untuk Masyarakat dengan Kebutuhan Khusus. Jakarta: Pusat Kajian Manajemen Pelayanan Lembaga Administrasi Negara.

Hadjon, Philipus M. 1987. Perlindungan Hukum Bagi Rakyat, Sebuah Studi tentang Prinsip-Prinsipnya, Penanganannya oleh Pengadilan dalam Lingkungan Peradilan Umum dan Pembentukan Peradilan Administrasi Negara. Surabaya: Bina Ilmu.

Harahap, R.P., dan Bustanuddin. 2015. Perlindungan Hukum terhadap Penyandang Disabilitas Menurut Convention on The Rights of Persons with Disabilities (CRPD). Jurnal Inovatif. Vol.VIII (I), pp. 17-29.

Harkrisnowo, Harkristuti. 2003. Reformasi Hukum di Indonesia: Quo Vadis?. Jakarta: Justika Sinar Publika.

Lijan, Poltak Sinambela dkk. 2006. Reformasi Pelayanan 
Vol.1 No.1 Juni 2019

Publik. Jakarta: Bumi

Aksara.

Ratminto dan Winarsih, A. S. 2009.

Manajemen Pelayanan.

Yogyakarta: Penerbit

Pustaka Pelajar.

Suhadi, Idup. 2003. Wawasan

Kebangsaan dalam

Kerangka Negara Kesatuan

Republik Indonesia. Jakarta:

Lembaga Administrasi

Negara.

Surjadi. 2009. Pengembangan

Kinerja Pelayanan Publik.

Bandung: Rafika Aditama.

Sutrisno, Slamet. 2006. Filsafat dan

Ideologi Pancasila.

Yogyakarta: Andi Offset.

Thohari, S. 2014. Pandangan

Disabilitas dan Aksesibilitas

Fasilitas Publik bagi

Penyandang Disabilitas di

Kota Malang. Indonesian

Journal of Disability Studies.

Vol. 1 (1), pp 27-37.

Undang-Undang No 4 Tahun 1997

tentang Penyandang Cacat.

Undang-Undang Nomor 19 Tahun

2011 tentang Pengesahan

Convention on The Rights of

Persons with Disabilities

(Konvensi Mengenai Hak-

Hak Penyandang

Disabilitas).

Undang-Undang Nomor 25 Tahun 2009 tentang Pelayanan

Publik. 